\title{
Erratum to: Can enemy release explain the invasion success of the diploid Leucanthemum vulgare in North America?
}

\author{
Sonja Stutz • Kateřina Štajerová • Hariet L. Hinz • \\ Heinz Müller-Schärer • Urs Schaffner
}

Published online: 28 March 2017

(C) The Authors 2017

\section{Erratum to: Biol Invasions (2016) 18:2077-2091 DOI 10.1007/s10530-016-1152-z}

The article "Can enemy release explain the invasion success of the diploid Leucanthemum vulgare in North America?", written by Stutz et al., was originally published Online First without open access. After publication in Volume 18, Issue 7, pp. 2077-2091, the author decided to opt for Open Choice and to make the article an open-access publication. Therefore, the copyright of the article has been changed to (C) The Author(s) (2017) and the article is forthwith distributed under the terms of the Creative Commons Attribution 4.0 International License (http:// creativecommons.org/licenses/by/4.0/), which permits use, duplication, adaptation, distribution and reproduction in any medium or format, as long as you give appropriate credit to the original author(s) and the source, provide a link to the Creative Commons license, and indicate if changes were made.

The online version of the original article can be found under doi:10.1007/s10530-016-1152-z.

S. Stutz $(\bowtie) \cdot$ H. L. Hinz · U. Schaffner

CABI, Rue des Grillons 1, 2800 Delémont, Switzerland

e-mail: s.stutz@cabi.org

S. Stutz $\cdot$ H. Müller-Schärer

Department of Biology, Ecology and Evolution, University of Fribourg, Chemin du Musée 10,

1700 Fribourg, Switzerland

\section{K. Štajerová}

Department of Invasion Ecology, Institute of Botany, The Czech Academy of Sciences, 25243 Průhonice, Czech Republic

K. Štajerová

Department of Ecology, Faculty of Science, Charles University in Prague, Viničná 7, 12844 Prague,

Czech Republic 